\title{
политология
}

DOI: $10.17805 / g g z .2017 .2 .4$

\section{Френсис Фукуяма: ради идеологически нагруженной русофобии все средства хороши}

\author{
А. Н. ИЛЬИН \\ ОМСКИЙ ГОСУДАРСТВЕННЫЙ ПЕДАГОГИЧЕСКИЙ УНИВЕРСИТЕТ
}

В последние годы средства массовой информации Запада проявили себя как средства массовой дезинформации. Одновременно с повышением градуса русофобии в них понижается градус объективности. В статье разоблачаются теоретические построения Ф. Фукуямы, которые являются необоснованно русофобскими и совершенно противоречащими исторической, политической и геополитической реальности. Делается вывод, что позиция Фукуямы антинаучна и идеологически нагружена. Тотальная безответственность за свои слова давно стала нормой среди многих политических и геополитических аналитиков «цивилизованного» мира.

Ключевые слова: Фукуяма; Украина; пропаганда; демократия; Крым; малазийский Боинг

\section{Francis Fukuyama: for the sake of ideologically loaded Russophobia by all means}

\author{
A. N. ILYIN \\ OMSK STATE PEDAGOGICAL UNIVERSITY
}

In recent years, the media of the West has proved itself as the media disinformation. Simultaneously with the increase of the degree of Russophobia in them decreases a degree of objectivity. The article exposes a theoretical construct Fukuyama, which are unreasonable Russophobic and absolutely contrary to the historical, political and geopolitical reality. The conclusion is that the position of Fukuyama unscientific and ideologically loaded. Total irresponsibility for his words has become the norm among many political and geopolitical analysts «civilized» world.

Keywords: Fukuyama; Ukraine; propaganda; democracy; Crimea; Malaysian Boeing

В современный так называемый информационный век актуализировалась проблема достоверности информации, четкого отделения действительных сведений от необъективных домыслов, подаваемых под видом достоверных данных. Чем большее количество сведений окружает нас, тем сложнее отделять объективный материал от идеологически нагруженного, искажающего восприятие реальности. Не только «молекулярные» формы пропаганды «играют» данными, это свойственно не одним лишь рекламным агентствам, подающим псевдоинформационный спам под видом досто-верного знания (Ильин, 2016). Это характерно не только повышающим свой политический капитал чиновникам местного уровня, в своих интересах трактующих исторические, политические, геополитические, экономические и другие сведения. Это свойственно самым широким пропагандистским акциям, переступающим границы отдельных стран.

Фальсификациями, инсинуациями, подменами тезисов и откровенной ложью насыщен сегодня наднациональный медиа-дискурс. Его содержательная направлен- 
ность отражает интересы глобальных (прежде всего американских) элит, а вещание распространяется отнюдь не только на США, но и на весь «цивилизованный» мир. В этом и заключается медийная сила США - оказывать (псевдо)информационное влияние на общественное мнение различных стран. Поэтому ожидаемо, что градус русофобии в последнее время возрос в «цивилизованном» мире; просто глобальные СМИ делают свое дело, не столько отражая новости, сколько их создавая, а вместе с этим и формируя определенные идеологические компоненты у своих многочисленных реципиентов. Само понятие «средства массовой информации» себя дискредитировало, и наиболее целесообразно было бы использовать понятие «средства массовой дезинформации». Однако как лодку назовешь, так она и поплывет, и сам по себе термин имеет весьма серьезное значение. Неудивительна осуществляемая в пропагандистских интересах «игра» терминами, когда то, что американцы применительно к недружественным странам презрительно называют коррупцией? применительно к своей стране именуют лоббированием, когда защитников Аонбасса называют сепаратистами, а кровавую, вероломную и террористическую операцию против них - антитеррористической. Описанный Оруэллом новояз живет и процветает. Поэтому более целесообразно именовать нынешнюю эпоху (псевдо)информационной. Сверхвлиятельные акторы медиа вносят посильный вклад в дерационализацию сознания людей. Но, если в этом контексте отдать предпочтение не идеологеме «бытие определяет сознание», а фразе "разруха в головах», следует констатировать, что дерационализация сознания может сформировать соответствующие виды деятельности и привести к экономической, социальной и политической деструкции.

На дезинформационный массив работают также авторитетные мыслители. Некоторые из них, правда, изначально получили авторитет благодаря созданию не какихто действительно описывающих и объясняющих реальность теорий, а, напротив, благодаря предложению теоретических построений, которые, претендуя на объективность, по сути своей являются псевдоинформационными и ошибочными. К теориям явно антиконструктивным, вносящим только сумятицу и хаос, деформирующим мировоззрение, относятся теории Френсиса Фукуямы.

В самом начале 1990-х годов Фукуяма создал совершенно антинаучный, но по форме весьма наукообразный, футурологический проект. В увесистой книге (Фукуяма, 2005) он предсказал неуклонность наступления для всего мира рыночной демократии, которая должна облагодетельствовать все человечество. Якобы неизбежная либерализация мира была названа им концом истории. Я сейчас не буду анализировать содержание этой книги, поскольку не оно является предметом рассмотрения данной статьи. Заинтересованный читатель может ознакомиться с подробным анализом книги о конце истории в рецензии, посвященной именно этому труду (Ильин, 2012). Скажу только, что, во-первых, именно не ограниченный государством рынок ведет к социальной поляризации, обогащению немногих и обнищанию большинства. Поэтому экономический либерализм, который всячески идеализировал и проповедовал Фукуяма, полностью противоречит социальному благу. Во-вторых, никакой воспеваемой Фукуямой либеральной демократии не пришло. Он доказывал прекращение войн и серьезных конфликтов вместе с либерализацией и демократизацией. И что мы видим? Прогноз ни на йоту не реализовался.

Причем Фукуяме, похоже, неведомы интеллектуальная честность и элементарная порядочность, поскольку он так и не признал очевидную ошибочность тезиса о конце истории. Спустя много лет после высказывания своего прогноза, после падения СССР 
как главного бастиона сопротивления либеральной демократии он продолжил настаивать на своем. Он по-прежнему называет рынок наилучшей формой организации человеческого общества. Он все также думает, что именно либеральная демократия завладеет будущим мира, что «модернити, представленная США и другими развитыми демократиями, останется доминирующей силой в мировой политике, а институты, олицетворяющие основные западные принципы свободы и равенства, продолжат распространяться по всему миру» (Фукуяма, 2002. Электронный ресурс). Ничего такого не реализуется в глобальных масштабах и, надо сказать, слава богу. Фукуяма продолжает интеллектуально изворачиваться в интервью, когда ему задают неудобные вопросы, хитрить, говорить, что, мол, его прогноз неправильно поняли. Но поняли его правильно, тем более книга Фукуямы предельно проста, не предоставляет широкого поля для толкований, и потому требуется совершить некое интеллектуальное извращение, чтобы неправильно ее понять. Хотя сегодня Фукуяма так рьяно не пропагандирует идею «конца истории». Видимо, понимает ее несостоятельность. Но и признать это боится, поэтому зарывает голову в песок, отпирается общими «рыночными» фразами, причем заведомо ошибочными. Широкая известность книги «Конец истории и последний человек» прямо пропорциональна степени абсурдности выдвигаемых в ней тезисов.

Аействительно, мир несправедлив, и на его несправедливость указывает, помимо прочих, литературный фактор; предельно широкую популярность нередко получают авторы, идеи и прогнозы которых ошибочны в самих своих основах. А чем выше известность подобных авторов, тем серьезней «разруха в головах». В последние годы Фукуяма отличился новыми «откровениями», и в этой статье мы предлагаем познакомиться уже не с Фукуямой 25-летней давности, который постулировал конец истории, а с Фукуямой нынешним, свежим, но по-прежнему занимающимся дешевыми инсинуациями, подлогами и лжесвидетельствами.

Вот уже три года взгляды мировой общественности прикованы к ситуации на Украине. Только взгляды эти совсем разные. Несмотря на отсутствие четкой и однозначной дихотомии типа «черное и белое» в широком спектре взглядов, несмотря на довольно Алинный континуум воззрений относительно происходящего на Украине, все же именно две точки зрения превалируют. С некоторой долей юмора (но юмор әтот не идет в ущерб объективности) их можно назвать американской и правильной. Согласно точке зрения США и «цивилизованного» западного мира, Незалежная пережила «революцию достоинства», в результате которой народ наконец-то сбросил олигархическое погрязшее в коррупции правительство, освободился от российского гнета и перешел на путь демократизации. Согласно правильной точке зрения, на Украине произошел антинародный государственный переворот, в результате которого укрепился олигархат, возросла коррупция, резко упал уровень жизни, власть почти по-либеральному отстранилась от своих социальных функций, страна утратила государственный суверенитет и перешла под внешнее - американское - управление. Происходящее на Украине не обошли своим вниманием 3. Бжезинский и Ф. Фукуяма. Новую книгу Бжезинского о связанных с Украиной событиях я ранее рецензировал (Ильин, Бжезинский об Украине... Электронный ресурс). В этой статье речь идет о тезисах Фукуямы.

Фукуяма принялся за старое занятие - за политическое бредогенерирование в своим прежнем стиле. Он практически полностью солидаризировался с той риторикой, которую провозглашают новоявленные украинские гауляйтеры и их вашингтонские хозяева, и его не беспокоит, что эта риторика противоречит реалиям. 
«Главным манипулятором социальными медиа оказалась Россия. Российское правительство запускало откровенные фейки - как, к примеру, «факты» распятия украинскими националистами маленьких детей, или заявления о том, что это украинские войска сбили малазийский Боинг в июле 2014 г. Эти же «источники» участвовали в дебатах относительно независимости Шотландии, Brexit и голландского референдума относительно Соглашения об ассоциации с Украиной, раздувая любой сомнительный факт, который ослабил бы проевропейские силы» (Фукуяма, Аобро пожаловать... Электронный ресурс). Эти слова Фукуямы, которые якобы изобличают манипуляцию, сами являются манипуляцией. На противоречащую фактам американско-украинскую пропаганду он закрывает глаза, а вот вполне правдивую информацию российских источников обвиняет во лжи. Фейк на фейке фейком погоняет в рисуемом Фукуямой мире. И неужели Россия - главный манипулятор? Наверное, она является таковым просто потому, что подобные Фукуяме авторы просто пытаются не замечать американских и проамериканских манипуляционных вбросов в мировое информационное пространство, которое делает его псевдоинформационным. И если уж Фукуяма обвиняет Россию в том числе в запуске Интернет-ботов и создании легионов троллей, заполняющих сеть лживой информацией, пусть он обратит внимание на множество таких фейков с украинской стороны в социальных сетях. Интернет заполонили сообщества с названиями типа «Патриоты Украины», «Герой Майдана», «Самооборона Майдану», «Анти-кацап» и т. А., и ряд пользователей - обычно с фейковыми страницами, где вместо имени/фамилии и аутентичной фотографии псевдоним и любая автатарка (трусость себя запечатлеть - это настоящий майдан-героизм!) - распространяют лозунги типа «Слава Украине». Но нет, их ведь не существует - просто потому, что Фукуяма так решил. Странно подумать - такой известный политолог тиражирует мнения, которые их носители никак не доказали, не предъявили никаких сведений. Так, американцы не предоставили точных доказательств причастности России к падению малазийского Боинга, но заявили, что точно знают о вине России, и аналитики типа Фукуямы сразу бегут трубить о России как агрессоре. Ведь получается именно так. Как это «по-современному», по-американски, по-украински - заявить необоснованный тезис, просто совершить вброс и никак его не обосновать.

Аля Фукуямы Россия - оккупант Крыма. Видимо, не знает он, что крымчане сами изъявили желание присоединиться к России. Было бы странно, если бы они захотели остаться в лоне Украины, к власти в которой, очевидно, пришли мародеры и преступники. Те, кто убеждают в том, что референдума не было, забывают о следующем. Никакие политические решения не способны инициировать такое огромное стечение народа, которое образовалось в день восторженного ликования, связанного с единством Крыма и РФ. Никакие самолеты и переправы не способны доставить такое количество людей по политическому заказу для массовки. Также те, кто убеждают, будто народ Аонбасса жестоко эксплуатируется ополченцами, будто местные жители находятся под гнетом «сепаратистов» и люто их ненавидят, пусть посмотрят на то, какое многотысячное скопление людей собралось на похоронах Арсения Павлова (Моторолы) - героического защитника Аонбасса от украинского нацизма. Такое огромное скопление не собралось бы никогда на похороны террориста и угнетателя. Киевско-американской стороной ни единого доказательства нарушений во время крымского референдума предоставлено не было, да и Фукуяма не удосужился обосновать сей факт оккупации. Он просто сказал и все. Есть такая шутка: крымчане не только голосовали, но и повсеместно радовались Единству под дулом авто- 
мата. Но русофобия делает свое дело, и миф об аннексии в мировых СМИ стал доминирующим.

Согласно Фукуяме Россия - ответственная сторона за падение малазийского Боинга. Странно подумать - такой известный политолог тиражирует мнения, которые их носители никак не обосновали, и бежит трубить о России как агрессоре. Ведь получается именно так. Сразу же после этой трагедии, без проведения какого-либо расследования, еще до нахождения черных ящиков, абсолютно голословно Порошенко поспешил обвинить в падении самолета пророссийских ополченцев, ведущих бои с украинской хунтой на юго-востоке страны. Не предоставив никаких доказательств в пользу своей версии, американские лоббисты также обвинили ополченцев и заодно Россию. Обвинение прозвучало до всякого расследования. Тогда же европейские СМИ принялись возлагать ответственность на Россию; какую версию старший в лице Америки заявил, ту и поддержали, не смущаясь отсутствием каких-либо данных.

Американцы сослались в качестве доказательств на... какие-то фотографии из социальных сетей. Аоказательство уровня детского сада подается на полном серьезе! Они заявили об имеющихся спутниковых снимках, но так их и не предъявили. Это в очередной раз говорит о том, что американцы готовы фальсифицировать информацию как угодно, лишь бы очернить своих противников. Интересно то, что украинцев как сторону конфликта приняли в следственный комитет по этому делу, а Россию туда не включили. Очевидно, так следствие вестись не может.

Курс самолета был изменен и пролегал над зоной боевых действий. Это вызывает вопросы, поскольку изменение курса должно согласовываться с авиадиспетчерами страны, над которой пролетает самолет. Украинцы, так уверенно обвиняющую Россию в этом теракте, не предоставляют аудиозапись разговора пилотов с авиадиспетчером. И самого диспетчера украинская сторона не предъявила. Более того, если в данной зоне идут военные действия, Украине следовало закрыть там воздушное пространство.

Аалее появляются сообщения, что этот Боинг сопровождал украинский истребитель. В украинских СМИ появилось «доказательство» причастности к теракту ополчения - запись разговора между ополченцами, в котором они признаются о сбитом ими самолете. Вот только незадача: выяснилось, что запись является фальсификацией, представляющей собой склеенные обрывки различных разговоров. Возникает вопрос: если Киев непричастен к теракту, стал бы он марать руки в создании таких фальсификаций? Если бы действительно самолет сбили ополченцы несуществующими «Буками», возникла бы необходимость в фабрикации улик, указывающих на ополченцев? Остается удивляться цинизму этой акции, хотя, с другой стороны, учитывая в целом деятельность киевской хунты, складывается впечатление, что у цинизма нет границ.

Черные ящики были найдены ополченцами. В случае их причастности стали бы они передавать находку в руки международной комиссии? Ведь это самоубийство, ибо раскрытие хранящейся информации вывело бы виновников на чистую воду. И оправАаться в таком случае уже невозможно. Если бы ополченцы были виновными, наиболее логичный шаг с их стороны - уничтожение черных ящиков, а не передача. Аумаю, трагедия с малазийским самолетом - та ситуация, где европейские политики все знают, но выражают несколько иную - принципиально антироссийскую и совершенно недоказанную - версию. И Фукуяма наверняка все прекрасно понимает, но деньги отрабатывать надо. Весьма примечательное событие: в январе 2017 г. после того, как 
голландские журналисты, побывав на Аонбассе, вернулись в родные края, нидерландская полиция конфисковала у них материалы (ноутбуки, телефоны, карты памяти и камеры), касающиеся трагедии с Боингом. Обоснование для задержания было связано с подозрением, что журналисты хотят скрыть находки. Только вот само подозрение не было ни на чем основано. А как же хваленая европейская гласность?

Как и подобает приличному американскому политологу, Фукуяма называет гражданским обществом тех, кто совершил революцию на Украине (Френсис Фукуяма, Путин делает ровно то... Электронный ресурс). По сути гражданским обществом именуются в том числе укро-националисты, откровенные фашисты, идейные наследники ОУН, убийцы, купленные американцами «патриоты». Рост нацизма, бандеровщины, абсолютная мифологизация СМИ - все это не выступает проявлением гражданственности. Понятно, что Фукуяма забывает об этих явлениях. Он предпочитает не видеть характерные именно для Украины переписывание истории, преклонение перед ОУН-УПА, факельные шествия, крайне русофобскую медиа-пропаганду, нацистов, скачущих под явно нетолерантные крики «Москаляку на гиляку». Он закрывает глаза на факты, согласно которым скакать под русофобские лозунги заставляли школьников.

Когда говорят о массовой политизации на той же Украине, забывают один статистический момент. Аа, на Майдан пришли тысячи человек. Но что собой представляют эти тысячи по сравнению с 44 миллионами жителей страны? Очевидно, в статистическом смысле они не являют собой большинство и потому едва ли имеют право говорить от имени народа и в своей речи выражать народную волю. Ааже если мы видим на площади десятки тысяч протестующих, это ничто по сравнению со сверхмиллионным городом и, тем более, с многомиллионной страной. Магия больших чисел заключается в том, что когда мы наблюдаем огромное скопление народа, нам кажется, будто здесь собралось социальное большинство, и практически вся страна внезапно локализовалась в одной месте, в этой многолюдной точке сингулярности. Соответственно, легок соблазн сделать вывод о событии всеобщей политизации и гражданского волеизъявления. Также следует учесть, что среди протестующего и скачущего меньшинства было много тех, кто целенаправленно работал за американские деньги на разжигание украинского пожарища. Поэтому неуместно произносить пафосные речи о гражданском обществе, которое наконец-то одержало верх над нелегитимным правительством. Поэтому понятие «общество» неприменимо ни к киевскому Майдану, ни к московской Болотной площади.

Фукуяма говорит, что украинцы удивили мир стремлением к переменам в 2004 и в 2014 гг. (Френсис Фукуяма об Украине, России и будущем. Электронный ресурс). Правильнее было бы сказать, что не украинцы удивили мир, а американское спонсирование. США потратили на украинскую революцию 2014 г. около \$5 млрд. Эту цифру озвучил не какой-нибудь конспирологично мыслящий русский патриот, а В. Нуланд. Впрочем, спонсирование от «мировых демократизаторов» не должно удивлять, поскольку поставлено на поток и устроило целый ряд революций в разных странах. Когда от США приходят деньги, дипломатическая помощь, освещение революции под «нужным» углом в СМИ, специалисты, представитель госдепа В. Нуланд и прочие ресурсы, совершение революции (даже самой антидемократической - но под демократичную риторику) намного облегчается.

И почему-то сейчас, когда на Украине экономическая, политическая и социальная ситуация значительно хуже, чем в бытность Януковича, украинцы нас не удивляют 
новой революцией. Ведь революционная ситуация располагает именно тогда, когда благосостояние падает. Видимо, сейчас нет поддержки от США. Аенег нет - революции нет. Вот действительно украинцы удивили бы, когда совершили бы революцию в ситуации отсутствия американской поддержки. Но, конечно, Фукуяма ни о какой помощи Штатов не говорит. Аа и вообе, несерьезно это - такому важному аналитику вещать правду.

А вот серьезным действием аналитика такого уровня является фраза о Путине как о человеке, настроенном помешать Украине стать успешным обществом (Фукуяма, Путин делает ровно то... Электронный ресурс) США отобрали у Украины суверенитет, заставили принять на высокие государственные посты иностранцев (редкостное позорище), требовали проводить ведущие к обнищанию населения либеральные реформы, поставили Украину на рельсы экономического закабаления и стимулировали правительство Незалежной брать кредиты и повышать госдолг. Но почему-то мешает украинцам стать успешным обществом именно Путин. Видимо, все эти действия американцев ведут украинское общество к успеху. Видимо, действия укро-властей, в результате которых катастрофически упал уровень жизни и миллионы украинцев стали переезжать - в том числе в Россию, направляют Незалежную на верный путь.

По мнению Фукуямы, Евромайдан - «это грандиозная битва за расширение современных форм демократического правления» (Фукуяма, Я очень обеспокоен... Электронный ресурс). Только проводился он весьма недемократично, с избиением Беркута, со всплеском нацистской эйфории, с совершенными революционерами убийствами и с серьезным вмешательством извне, что в совокупности неотвратимо сдирает ярлык демократичности. Но Фукуяма об этом не знает или думает, что знать об этом ему не нужно. Просто американская элита сама определяет, где демократия, а где тоталитаризм. И получается, что демократия там, где правительство реализует интересы американской власти и корпораций, даже в ущерб интересам собственного народа.

Реальность говорит о катастрофическом скачке коррупции в постмайданной Украине, а Фукуяма утверждает, что новым руководителям удалось снизить коррупцию и внедрить принципы публичного менеджмента в процесс управления (там же). Широко известен следующий императив: факты остаются фактами, а интерпретации могут быть разными. Вот честные этически добросовестные ученые спорят в интерпретациях, не трогая самих фактов. Но бесчестные этически недобросовестные «товарищи» начинают подменять факты, изобретать их, конструировать, а потом доказывать, что их мыслительные (порой весьма изощренные) конструкции и есть непреложные истины объективной реальности. Также делает Фукуяма, постулируя, но не доказывая, снижение коррупции новой властью Украины, демократизации и господство принципов публичного менеджмента. Какой публичный менеджмент, когда процветает авторитаризм, СМИ тиражируют одни и те же мифы про Россию, Украину и Майдан, в медиа-пространство не допускаются альтернативные точки зрения? Так, общественность Киева выступала против проведения гей-парада, а парад все равно провели. Видимо, гей-парад - это необходимый элемент демократии, и даже если народ это мероприятие бойкотирует, все равно его следует проводить. Видимо, запрет на коммунистические взгляды - тоже проявление демократичного публичного менеджмента. Такова она, западно-американская демократия на Украине. Главное - не сказанное народом, а то, что элита посчитала демократичным. Наконец, смешно читать россказни про публичный менеджмент, взлет качества управления и т. А. при взгляде 
на многие совершенно бредовые высказывания представителей истеблишмента Украины, при взгляде на О. Аяшко, который, стоя за трибуной в Верховной Раде, клал себе в рот кусочки земли, приговаривая об украинском черноземе, который можно намазывать на хлеб и есть. Ну чем не реклама сельского хозяйства и плодородия? Можно ли представить, чтобы действительно серьезный политик позволял себе такие действия? Или просто серьезность, ответственность, профессионализм, интеллектуальное развитие сегодня не в тренде среди элит?

Фукуяма говорит, что был поражен силой и организационной способностью украинского общества сопротивляться несправедливости и добавляет, что украинская модель может быть примером для иных стран в борьбе с авторитарными, патерналистскими и коррупционными режимами (Фукуяма об Украине и мире). Во-первых, чему тут поражаться? Аа, Майдан был заполнен. Но, как уже говорилось, в социологическом плане революционеры - вовсе не большинство, и они не могут представлять украинское общество. Во-вторых, какая сила и организационная способность, если у протестующих не было никаких аргументированных и рациональных программ? Великие революции совершаются не под иррациональные и манипуляционные абсолютно пустые в содержательном смысле лингвистические штампы (как это было на Украине в 2004 и в 2014 г.), а под конкретные рационально выстроенные, продуманные программы. Великие революции прошлого опирались на глубокую идеологию, выработанную великими мыслителями. На Майдане не было предложено никакой «когнитивной картографии». Медиа-кампания, сопровождающая Майдан, была в полной мере суггестивной и мистической. Никакой выраженной и подкрепленной доказательной базой идеологии не предлагалось. Не было предложено никакого четкого плана переустройства Украины, проекта новой страны, кроме мифической интеграции в Европу. Ни о каком анализе её проблем и выработке путей решения речи не шло. Все происходило на уровне дешевых бессодержательных лозунгов типа «Кто не скачет, тот москаль», «Москаляку на гиляку», «Украина це Европа»и т. А. Без глубокой идеи, без человекоцентричных идеалов революция - это преступление, причем она является большим преступлением, отменяющим малое преступление в виде дореволюционного режима. Имелись только антироссийские лозунги и несбыточные (по крайней мере, принимая во внимание именно рвущихся к власти людей - их человеческий облик и уровень профессионализма) популистские цели типа свергнуть олигархат, победить коррупцию и войти в Европейский Союз. Ни одна из этих целей не была достигнута. Более того, они были достигнуты в точности до наоборот. Влияние олигархата только усилилось, авторитаризм упрочил свои позиции (о чем говорит хотя бы однообразный медиа-контент), а коррупция в разы увеличилась. Поэтому неясно, кто и зачем будет брать пример с украинской модели, радетели за которую боролись с коррупцией, патернализмом и авторитаризмом и в результате только усилили коррупцию и авторитаризм. Патернализм, конечно, победили, а вместе с ним и социальное государство, ответственное перед народом. Поэтому низвержение патернализма - не достижение. Фукуяма придает отрицательное значение патернализму, видя в нем одно из проявлений недемократических государств. Однако то, что называется с презрением «патернализм», связано с тем, что именуется социальной политикой. Именно ее на Украине не осталось, она была побеждена. С таким же успехом во фразе об украинской модели как примере борьбы с авторитаризмом словосочетание «украинская модель» можно заменить, например, на «пиночетовскую модель». 
Представители американской стороны любят вещать, что вот теперь, после Майдана, Украина достигла независимости. Просто тотальная зависимость от США на их оруэлловском языке называется независимостью. Явно неубедительны тезисы преимущественно американских авторов, что, мол, теперь Украина свободно выбирает, с кем ей сотрудничать, а правительство стало «в доску» народным. Парадоксально: именно когда политика Украины утратила суверенность и полностью отошла от народной воли, американские и западные аналитики стали называть ее суверенной и народной.

Конечно, Фукуяма не утруждает себя доказывать высказанные им тезисы. Он просто бросается ими, видимо, считая, что предоставление доказательной базы не является необходимостью. Впрочем, он давно уже проявил себя как политический аналитик и футуролог, аналитика которого противоречит реальности, если не сказать, законам природы, а футурология просто не сбывается (о чем мы говорили в начале статьи). Одна только его полностью противоречащая политическим реалиям вера в Штаты как форпост распространения демократии в мире чего стоит! Только забывает он сказать о связях спецслужб США с тоталитарным правительством Пиночета.

Приведем лишь некоторые факты. Американцы руками ЦРУ и корпорации Бигтел осуществили кровавый государственный переворот в Индонезии и привели к власти генерала Сухарто. Индонезию времен Сухарто неподотчетные западные экспортнокредитные агентства обложили кредитами; в результате кредитования семья Сухарто обогатилась на откатах, экономика страны ослабла, экология была сильно нарушена. Более того, американцы (по инициативе Киссинджера) сподвигли Сухарто напасть на Восточный Тимор, поскольку Штатам показалось, что там укореняется коммунистическая идеология. Америка обеспечила индонезийцев оружием, едой, амуницией для войны. По тайному решению Никсона и Киссинджера во время вьетнамской войны США бомбили Камбоджу, ее гражданское население, пытаясь уничтожить находящиеся на ее территории склады вьетнамских коммунистов; война унесла около 500 тыс. жизней камбоджийцев, а ведшего нейтральную политику Камбоджи принца Сианука ЦРУ свергло. Ради недопущения утечки информации о позорной войне в Камбодже было принято решение в «демократической» державе прослушивать телефоны журналистов и представителей правительства, и когда оно стало известным, разразился Уотергейтский скандал. Примеры вероломного вторжения Штатов, приводящего к страданиям целых народов, можно приводить очень долго. Но для Фукуямы Штаты - форпост демократии. Он обходит стороной вопрос о совершенно наглой и преступной войне с Вьетнамом, вероломных бомбежках Югославии, Ирака и Иивии. Забывает он о том, что везде, где американский сапог совершил цветную революцию, везде, где похозяйничали проамериканские МВФ и Всемирный банк, вместо демократизации произошли демодернизация, экономический спад и низвержение народа в нищету.

Фукуяма, как и Бжезинский (Бжезинский, 2015), предлагает предоставить Украине обучение и серьезное военное оборудование (Френсис Фукуяма: Путин ведет очень Авуличную игру. Электронный ресурс). Вот такая дипломатия! Аанное предложение фундировано невысказанным желанием окончательно рассорить Украину и Россию. Ведь Россия - серьезный геополитический противник, который нельзя оставлять в покое. Ее следует ослаблять различными способами - войной (естественно, чужими руками), санкциями, дипломатическим давлением и т. А. Однако аналитики типа Фукуямы прикрывают тезис о помощи Украине словами о свободе, о безопасности, 
о демократии, о неправоте России, об аннексии Крыма и т. А. Истинные стремления не проговариваются.

У России есть свои ответы на все претензии Запада, и они более аргументированны, чем его претензии. Но Запад не хочет даже видеть эти ответы, не говоря о том, чтобы их принимать. Поэтому сложно и почти бессмысленно доказывать, что наши ответы опираются на действительные факты, что они логичней и содержательно глубже высказанных в российский адрес претензий. Ведь интерес на чаше весов перевешивает правду. Есть у США интерес гнобить Россию, вот и закрывают они глаза на всю правду, как в 2008 г. закрывали их на истину относительно грузинского инициирования войны, да еще при поддержке Америкой. Оккупированная американскими военными базами Европа, но продолжающая утверждать о своей независимости и демократичности, вынуждена прогибаться под Штатами и подхватывать в своих СМИ американский антироссийский абсурдный медиа-контент, и потому ей тоже правда неинтересна. Ведь говорить правду для Европы - значит провоцировать недовольство Штатов. К сожалению, интересы сильнее истины. Перефразируем известную фразу из философии науки: если факты противоречат интересам, тем хуже для фактов.

Фукуяма заявляет: «Авторитарные режимы, такие как Россия, Китай и Индия, чувствуют себя все более уверенно, используя риторику этнического национализма, нетолерантного к другим народам» (Евромайдан вдохновил мировую политику. Электронный ресурс). Интересно, где же, в каких выступлениях российских политиков Фукуяма услышал риторику этнонационализма, да еще и нетолерантного к другим народам. Неудивительно, что он предпочел не конкретизировать этот тезис, не говорить о конкретных выступлениях конкретных лидеров, не ссылаться на те или иные слова, подтверждающие этнонационализм как магистральное явление для современной России. Видимо, таких выступлений и не было. Но почему-то Фукуяма, как и Бжезинский, страдает удивительной близорукостью, не позволяющей ему увидеть вполне зримый факт: на Украине под известные речевки в открытую нагнетали русофобию и продолжают нагнетать сейчас путем официальных (а не каких-то маргинальных) СМИ, а в России нет никакой украинофобии, даже такого понятия не существует. Правда, обычно укро- «патриоты» называют украинофобией неприятие русскими самих укро- «патриотов». Но тут не стоит путать понятия: свидомые и украинцы - вовсе не одно и то же. Поэтому неуважение к свидомым - это не украинофобия, а проблема самих свидомых.

Почему-то ни Бжезинский, ни Фукуяма не усматривают в расцветающей ныне польской и прибалтийской русофобии этнонационализма и нетолерантности. Похоже, толерантности заслуживает исключительно западный мир, который вещает о принципах толерантного отношения к другим, но позволяет себе любые выходки, противоречащие этим принципам. Наконец, когда США заявляют о необходимости защищать американцев, проживающих в других странах, это называется национальными интересами. Когда РФ говорит о защите русских, находящихся за рубежом, сразу следуют обвинения в этнонационализме и в интолерантности. Хороши же западные стандарты!

Сейчас почти весь «цивилизованный» мир ополчился против несуществующей российской агрессии. Штатами была принята в 2015 г. «Стратегия национальной безопасности», где речь идет не о том, быть ли США глобальным лидером, а о том, как именно Штаты должны осуществлять свое глобальное лидерство. Согласно документу, одно из наглядных проявлений мирового лидерства США сегодня - факт, что именно 
Штаты мобилизуют и направляют глобальные усилия по противостоянию российской агрессии и «наказанию» России (Алексеев, Алексеева, 2016). Только возникает вопрос: кто же будет мобилизовать и направлять глобальные усилия по противостоянию американской агрессии. Более того, необходимо противодействовать также информационной агрессии США, ведь огульное ни на чем не основанное обвинение России в агрессии - проявление Штатами агрессии в информационной войне.

Фукуяма тиражирует проукраинские мифы о России как агрессоре в Грузии; данный миф даже на Западе давно развенчали, но Фукуяма, похоже, еще об этом не знает. Теперь взглянем в лицо правде. Режим Саакашвили поддерживался Америкой: за пять лет военный бюджет Грузии возрос с $\$ 30$ млн до $\$ 1$ млрд, перед нападением на Осетию в грузинском министерстве обороны работали американские военные инструктора и проводились профинансированные Пентагоном грузино-американские военные учения (Михайлов, 2008). Ааже 3. Бжезинский пишет о том, что США после войны 2008 г. перечислили Грузии \$1 млрд (Бжезинский, 2013). Именно по указке США Саакашвили начал войну. Американский политик и политолог П. Бьюкенен называет Саакашвили любимцем Вашингтона. Бьюкенен негодует, что США лезут не в свое дело, поддерживают интервенцию Грузии, фальсифицируют данные об этой войне мифами об агрессивном вторжении России, признают Южную Осетию и Абхазию провинциями Грузии (Бьюкенен. Электронный ресурс). Аюбимчик Вашингтона сейчас уже очевиден такой статус бывшего грузинского лидера - особенно после того, как американцы его не бросили и протолкнули к посту мәра Одессы в постмайданной Украине.

Участие России в грузино-осетинском конфликте на стороне потерпевшего, то есть Осетии, противоречит интересам неявно выступающих на стороне агрессивной Грузии США. Неудивительно, что власти США сразу потрудились развернуть против России широкомасштабную информационную войну, а политологи типа Фукуямы ее поддержали. Все мировые, а не только американские, «независимые» СМИ буквально заиграли в унисон, демонстрируя стреляющих по Цхинвалу грузинских солдат и называя их русскими.

Россию огульно обвиняли в неоправданной агрессии - в том, чего она не совершала. Агрессоры инспирировали России преступления, которые они сами совершили. Натравливанием Грузии на Осетию и ввязыванием России в войну был сформирован очередной повод для обвинения России в глазах мировой общественности. При участии в войне Россия неумолимо представляется агрессором в лагере своих противников и в принципе во всем мире. Ааже без участия в войне она таковой представляется; ведь с Украиной РФ не воюет, но в западных медиа они находятся в военном конфликте. Миф в мировых СМИ преподносится как истина, якобы неподвластная переосмыслению. Заявили с однозначной уверенностью, что Россия агрессор, значит, она и агрессор. А поскольку об этом говорили во всех мировых СМИ, да еще использовали множественные повторы, ретрансляцию мифа, из-за широты его тиражируемости он стал восприниматься в качестве монументальной истины, с которой никто не спорит. Следовательно, миф, оставаясь мифом, то есть не исторической истиной, субъективно, в сознании воспринявших его людей и сообществ представляется историзированным, реальным, не поддающимся переинтерпретации. Так и произошло с Россией, которая проявила неоправданную военную агрессию не в реальности, а в широчайшем ментальном пространстве. Конечно, Фукуяма не удосужился предъявить какие-то действительных доказательства в пользу идеи о российской агрессии. 
Фукуяма также решил продемонстрировать исторические знания, касающиеся Второй мировой войны. В книге «Америка на распутье» он заявил, что США сыграли ключевую роль в поражении нацистской Германии и Японии. И далее автор делает ссылку, в которой сказано, что с этой точкой зрения могут не согласиться многие читатели издания книги на русском языке. Конечно, не согласятся с такой антиисторической трактовкой. К тому же Фукуяма снова не дает никаких - даже минимальных - аргументов в защиту своего тезиса. Он его просто постулирует. По Фукуяме, неограниченная мощь Америки «привела к абсолютно правомерному с точки зрения морали (по всеобщему мнению) исходу Второй мировой войны» (Фукуяма, 2007: 32). Только что значит «по всеобщему мнению»? Где эта всеобщность? Именно СССР потерял 26 млн. жизней, именно СССР уничтожил большую часть немецких солдат, но все равно ключевая роль принадлежит США. Тезис, буквально насилующий - да еще в предельно извращенной форме - историческую реальность. А что сделала Америка? Подвергла жесточайшей бомбежке с применением напалма Арезден, который имел мало стратегической значимости, причем разбомбила его вместе с мирными жителями.

Фукуяма пишет, что западные институты и ценности либерализма и демократии необходимы почти всему миру. То есть, он выступает за культурный универсализм Запада, хотя понимает, что далеко не все народы, в силу специфических особенностей своих культур, готовы внедрять западные ценности. Приведем весьма длинную цитату. «Но западные институты, равно как и научный метод, который был открыт на Западе, обладают универсальной применимостью. Существует глубинный исторический механизм, который ведет к долгосрочной конвергенции поверх культурных границ: во-первых, наиболее сильно в экономике, затем в сфере политики, и наконец (в наиболее отдаленной перспективе) - в культуре. В первую очередь этот процесс движется вперед благодаря современной науке и технологиям, способности которых создавать материальное богатство и орудия войны настолько велики, что делают науку и технологии необходимыми для всех обществ. Технология полупроводников или биомедицина имеет ту же ценность для мусульман или китайцев, что и для Запада, а необходимость овладеть технологиями предопределяет заимствование особых экономических институтов, таких как свободные рынки и главенство закона, которые обеспечивают рост. Современные ориентированные на технологии рыночные экономики преуспевают на основе индивидуальной свободы - то есть системы, в которой скорее индивиды, а не правительства принимают решения о ценах или процентных ставках» (Фукуяма, Началась ли история опять? Электронный ресурс). Не наблюдается никакого глубинного исторического механизма, ведущего к конвергенции поверх культурных границ. Аа, наука и технологии нужны всем. Однако обладание технологиями вовсе не связано с заимствованием свободных рынков и экономических свобод. Наиболее наглядное доказательство - Советский Союз, в котором отсутствовала рыночная экономика, не пахло экономическими свободами, но наука и технологии развивались значительно быстрее, чем во многих странах «цивилизованного» мира. Поэтому тезис о связанности науки и технологий со свободным рынком - очередной идеологический штамп и не более того. Такой же штамп - пропагандируемый Фукуямой тезис о том, что экономическое развитие ведет к либеральной демократии. Аа, экономический рост способствует возникновению образованного среднего класса, требующего защиты своих прав. Но вовсе не факт, что его представители примут именно либеральную идеологическую ориентацию. А если говорить про Украину, то, используя 
логику все того же Фукуямы, следует констатировать: так как вместо экономического роста там упадок по всем главным показателям, значит, происходит и отход от демократии - все дальше и дальше, чем это было при более экономически состоятельной Украине времен Януковича.

В общем, Фукуяма катастрофически ошибся тогда, когда предсказывал необратимое и благостное для всего мира наступление либеральной демократии, и не намного менее катастрофически ошибается теперь. Если уж человеку выпала судьба быть бредогенератором и противоречить реальности постоянно, что тут можно сказать. Остается только посочувствовать. Похоже, верным будет принцип: «Послушай Фукуяму и сделай все наоборот».

Как Бжезинский, так и Фукуяма, выступая за гегемонию США в мире и нередко переходя от строгого научного анализа к вербализации тиражированных в западной прессе и ничем не подкрепленных мифов, расписываются в своей ангажированности. Считается, что Бжезинский работает в дисциплинарном пространстве геополитики. Однако его деятельность выходит далеко за данную научную область и вторгается в антинаучную сферу идеологизаторства и пропаганды. Считается, что Фукуяма работает в пространстве политической философии и футурологии. Однако его деятельность скорее связана с теми же идеологизаторством, пропагандой и лжепрогнозами. Футурология Фукуямы оборачивается лжефутурологией. Мнение Фукуямы далеко от объективности. В нем проглядывают интересы, противоречащие научной непредвзятости.

Недавние выступления политических и геополитических аналитиков «цивилизованного» мира в очередной раз доказали верность тезиса: в их среде тотальная безответственность за свои слова давно стала нормой. Значит, из аналитиков они превращаются в антианалитиков, идеологически ангажированных, работающих по принципу «чего изволите?» сказочников по содержанию и ученых по форме. Но всего лишь по форме.

\section{СПИСОК АИТЕРАТУРЫ}

Алексеев, А. П., Алексеева, И. Ю. (2016) Информационная война в информационном обществе // Вопросы философии. № 11. С. 5-14.

Бжезинский, 3. (2013) Стратегический взгляд: Америка и глобальный кризис; пер. с англ. М. Аесятовой. М. : АСТ. 285, [3] с.

Бжезинский, 3. (2015) Украинский шанс Аля России. М. : Алгоритм. 240 с.

Бьюкенен, П. Зачем мы дразним медведя? [Электронный ресурс] // ИНOCMИ.PУ. URL: http://inosmi.ru/usa/20110829/173957126.html (дата обращения: 22.02.2017).

«Евромайдан вдохновил мировую политику»- Френсис Фукуяма об Украине и глобализации. [Электронный ресурс]. URL: http://reed.media/fukuyama/ (дата обращения: 18.02.2017).

Ильин, А. Н. Бжезинский об Украине: анализ или идеологизаторство? [Электронный peсурс] // Россия навсегда. Народные ведомости. URL: http://rossiyanavsegda.ru/read/4312/ (дата обращения: 15.02.2017).

Ильин, А. Н. (2012) Возможен ли конец истории по Ф. Фукуяме? [Электронный ресурс] // Информационный гу- манитарный портал «Знание. Понимание. Умение». № 3 (май - июнь). URL: http://www.zpu-journal.ru/e-zpu/2012/3/Ilyin_End-of-History-Fukuyama/ (дата обращения: 22.08.2014).

Ильин, А. Н. (2016) Псевдоинформационная сущность рекламы и брендинга в обществе потребления // Информационное общество. № 1. С. 33-39.

Михайлов, И. (2008) Момент истины для России [Электронный ресурс] // Журнал «Зиновьев». №3. URL: http://zinoviev.org/chteniya/elzhur/moment-istiny/ (дата обращения: 22.06.2015). 
Френсис Фукуяма: Путин ведет очень двуличную игру [Электронный ресурс] // Крым. Реалии. URL: http://ru.krymr.com/a/francis-fukuyama-putin-ukraina/26572453.html (дата обращения: 17.02.2017).

Френсис Фукуяма: Путин делает ровно то, что делал Гитлер [Электронный ресурс] // Украинская правда. URL: http://www.pravda.com.ua/rus/articles/2014/08/27/7035903/ (дата обращения: 17.02.2017).

Френсис Фукуяма об Украине, России и будущем. [Электронный ресурс]. URL: http://www.20khvylyn.com/opinion/mind/opinion_10347.html (дата обращения: 16.02.2017).

Фукуяма: $Я$ очень обеспокоен перспективами развития Украины [Электронный ресурс] // Гордон. URL: http://gordonua.com/news/worldnews/fukuyama-ya-ochen-obespokoen-perspektivami-razvitiya-ukrainy-103610.html (дата обращения: 14.02.2017).

Фукуяма, Ф. Аобро пожаловать в мир Аональда Трампа [Электронный ресурс] // Новое время. URL: http://nv.ua/opinion/fukyama/dobro-pozhalovat-v-mir-donalda-trampa-389040.html (дата обращения: 27.02.2017).

Фукуяма об Украине и мире [Электронный ресурс]. URL: http://trim-c.livejournal.com/ 1264521.html (дата обращения: 16.02.2017).

Фукуяма, Ф. (2007) Америка на распутье: Аемократия, власть и неоконсервативное наслеАие. Пер. с англ. А. Георгиева. М. : АСТ ; АСТ МОСКВА ; ХРАНИТЕ АЬ. 282, [6] с.

Фукуяма, Ф. (2005) Конец истории и последний человек. М. : АСТ ; Ермак. 588, [4] с.

Фукуяма, Ф. (2002) Началась ли история опять? [Электронный ресурс] // Русский журнал . URL: http://old.russ.ru/politics/20021106-fuk.html (дата обращения: 18.02.2017).

\section{REFERENCES}

Alekseev, A. P. and Alekseeva, I. Yu. (2016) Informacionnaya vojna v informacionnom obshchestve. Voprosy filosofii, no. 11, pp. 5-14. (In Russ.).

Bzhezinskij, Z. (2013) Strategicheskijvzglyad: Amerika i global'nyj krizis; per. s angl. M. Desyatovoj. Moscow, ACT. 285, [3] p. (In Russ.).

Bzhezinskij, Z. (2015) Ukrainskij shans dlya Rossii. Moscow, Algoritm. 240 p. (In Russ.)

B'yukenen, P. Zachem my draznim medvedya? INOSMI.RU [online] Avaible at: http://inosmi.ru/ usa/20110829/173957126.html (access date: 22.02.2017). (In Russ.).

"Evromajdan vdobnovil mirovuyu politiku» Frensis Fukuyama ob Ukraine $i$ globalizacii [online] Avaible at: http://reed.media/fukuyama/ (access date: 18.02.2017). (In Russ.).

Ilyin, A. N. Bzhezinskij ob Ukraine: analiz ili ideologizatorstvo? Rossiya navsegda. Narodnye vedomosti [online] Avaible at: http://rossiyanavsegda.ru/read/4312/ (access date: 15.02.2017). (In Russ.).

Ilyin, A. N. (2012) Vozmozhen li konec istorii po F. Fukuyame? Informatsionnyi gumanitarnyj portal «Znanie. Ponimanie. Umenie», no. 3 (maj - iyun') [online] Avaible at: http://www.zpu-journal.ru/e-zpu/2012/3/Ilyin_End-of-History-Fukuyama/ (access date: 22.08.2014). (In Russ.).

Ilyin, A. N. (2016) Psevdoinformacionnaya sushchnost' reklamy i brendinga v obshchestve potrebleniya. Informacionnoe obshchestvo, no. 1, pp. 33-39. (In Russ.).

Mihajlov, I. (2008) Moment istiny dlya Rossii. Zhurnal «Zinoviev», no. 3 [online] Avaible at: http://zinoviev.org/chteniya/elzhur/moment-istiny/ (access date: 22.06.2015). (In Russ.).

Frensis Fukuyama: Putin vedet ochen' dvulichnuyu igru. Krym. Realii [online] Avaible at: http://ru.krymr.com/a/francis-fukuyama-putin-ukraina/26572453.html (access date: 17.02.2017). (In Russ.).

Frensis Fukuyama: Putin delaet rovno to, chto delal Gitler. Ukrainskaya pravda [online] Avaible at: http://www.pravda.com.ua/rus/articles/2014/08/27/7035903/ (access date: 17.02.2017). (In Russ.).

Frensis Fukuyama ob Ukraine, Rossii i budushchem [online] Avaible at: http://www.20khvylyn.com/opinion/mind/opinion_10347.html (access date: 16.02.2017). (In Russ.)

Fukuyama: YA ochen' obespokoen perspektivami razvitiya Ukrainy. Gordon [online] Avaible at: http://gordonua.com/news/worldnews/fukuyama-ya-ochen-obespokoen-perspektivami-razvitiyaukrainy-103610.html (access date: 14.02.2017). (In Russ.). 
Fukuyama, F. Dobro pozhalovat' v mir Donal'da Trampa. Novoe vremya [online] Avaible at: http://nv.ua/opinion/fukyama/dobro-pozhalovat-v-mir-donalda-trampa-389040.html (access date: 27.02.2017). (In Russ.).

Fukuyama ob Ukraine $i$ mire [online] Avaible at: http://trim-c.livejournal.com/1264521.html (access date: 16.02.2017). (In Russ.).

Fukuyama, F. (2007) Amerika na rasput'e: Demokratiya, vlast' $i$ neokonservativnoe nasledie. Per. s angl. A. Georgieva. Moscow, AST ; AST MOSKVA. ; HRANITEL'. 282, [6] p. (In Russ.). Russ.).

Fukuyama, F. (2005) Konec istorii i poslednij chelovek. Moscow, AST ; Ermak. 588, [4] p. (In

Fukuyama, F. (2002) Nachalas' li istoriya opyat'? Russkij zhurnal [online] Avaible at: http:// old.russ.ru/politics/20021106-fuk.html (access date: 18.02.2017). (In Russ.).

Аата поступления: 28.02.2017 2.

Ильин Алексей Николаевич - кандидат философских наук, доцент кафедры практической психологии Омского государственного педагогического университета. Адрес: Россия, г. Омск, наб. им. Тухачевского, 14. Тел./факс: +7 (381-2) 23-12-20. Эл. адрес: ilin1983@yandex.ru

Ilyin Alexey Nikolaevich, Candidate of Philosophy, Associate Professor, Department of Practical Psychology, Omsk State Pedagogical University. Address: 14 Tukhachevsky Embankment, Omsk, Russia. Tel./Fax: +7 (381-2) 23-12-20. E-mail: ilin1983@yandex.ru

Аля илитирования:

Ильин А. Н. Френсис Фукуяма: ради идеологически нагруженной русофобии все средства хороши [Электронный ресурс] // Горизонты гуманитарного знания. 2017. №2. URL: http:// journals.mosgu.ru/ggz/article/view/461 (дата обращения: дА.мм.гггг). DOI: 10.17805/ggz.2017.2.4 